\title{
Violência urbana e saúde mental: por narrativas em primeira pessoa
}

I 1 Patricia Cavalcanti Schmid, ${ }^{2}$ Octavio Domont Serpa Junior I

Resumo: O artigo apresenta um estudo qualitativo acerca da temática violência urbana e saúde mental através das narrativas de pacientes de uma clínica da família localizada em área muito violenta. Empregou-se a metodologia da Medicina Narrativa e foram entrevistadas três pacientes da clínica da família, selecionadas pelo seu pedido de cuidado em saúde mental e intensa experiência com violência. São analisadas as narrativas, que foram gravadas, e depreendidos elementos que podem indicar os agravos proporcionados pela experiência violenta à saúde mental das entrevistadas, a saber, trauma, "desterritorialização" afetiva, prolongamento do luto, intervenção do poder dos códigos da violência na autonomia subjetiva e identitária.

> Palavras-chave: violência urbana; saúde mental; narrativas.

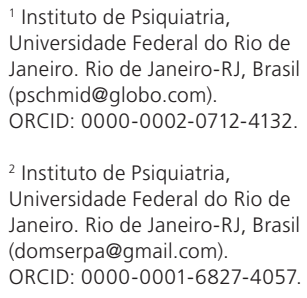
(pschmid@globo.com). ORCID: 0000-0002-0712-4132.

2 Instituto de Psiquiatria, Universidade Federal do Rio de Janeiro. Rio de Janeiro-RJ, Brasil (domserpa@gmail.com). ORCID: 0000-0001-6827-4057.

Recebido em: 09/10/2018 Revisado em: 29/05/2019 Aprovado em: 03/06/2019 


\section{Introdução}

Quando falamos em violência urbana, o termo nos remete a uma ampla variedade de fenômenos violentos. Há um conjunto de eventos sofridos por todos aqueles que vivem em centros urbanos, notadamente os moradores das comunidades de perfil popular. Os homicídios no Brasil são uma questão nacional de saúde pública, sendo a principal causa de morte de jovens entre 15 e 24 anos, moradores das periferias e áreas metropolitanas dos centros urbanos. Os estudos reiteram a força com que os intermináveis confrontos violentos pelo controle de mercados ilegais de drogas e armas afetam de modo desigual os grupos, vitimando principalmente moradores de localidades pobres (CARDOSO et al., 2016, p. 1.278). A exposição frequente a situaçôes de violência gera uma sensação de insegurança, medo e uma necessidade de mudança regular no cotidiano. Associadas a esses elementos temos as questôes da urbanização desenfreada, dos desafios socioeconômicos, dos conflitos sociais que, adicionadas à violência urbana, dão ao cenário mais dramaticidade.

Estudos têm avaliado os impactos da violência na saúde mental das populaçóes submetidas, muito embora não tenhamos, ainda, um número significativo de trabalhos nesse sentido no Brasil. Quando pensamos em agravos à saúde mental, há descrição de que "o sentimento de insegurança parece funcionar como um mediador entre a exposição à violência e as condiçôes mórbidas através das mudanças comportamentais, como adoção de comportamentos de risco, isolamento social e comprometimento do cuidado em saúde” (PERES; RUOTTI, 2015, p.74). Estudos epidemiológicos vêm apontando elevada incidência de sintomas sugestivos de transtornos mentais, a saber transtornos depressivos, de ansiedade (incluindo transtorno de estresse pós-traumático - TEPT) e mais quadros difusos, relacionados a vivências de violência armada em territórios vulneráveis (GONÇALVES; QUEIROZ; DELGADO, 2017, p. 19). Entretanto, a maioria das pesquisas que relacionam experiências de violência à incidência de transtorno mental não tem sido conclusiva, apontando a complexidade do fenômeno, que náo pode ser reduzido à questão nosológica.

O artigo aqui exposto apresenta uma investigação conduzida através de métodos qualitativos de base narrativa, a partir da vivência como profissionais de saúde numa Clínica da Família localizada numa comunidade com alto índice de violência urbana no Rio de Janeiro. O objetivo foi acessar a profundidade psíquica dos impactos 
da violência urbana na subjetividade de pessoas que viveram essas experiências, no sentido da compreensão e da produção de conhecimento a partir de um "dar voz" à experiência. Foram analisadas narrativas de pacientes com queixas de sofrimento psíquico e histórico de experiência com violência urbana.

A Medicina Narrativa como modelo para a prática médica se define como

[...] medicina biopsicossocial, a medicina centrada no paciente com olhares amplos para o paciente e a doença [...] fornece os meios para entender as conexôes pessoais entre paciente e médico, o significado da prática médica para o médico individualmente, a coletividade profissional médica e para o discurso da medicina na sociedade a que serve (CHARON, 2001, p. 1897, tradução nossa).

O conhecimento narrativo leva a locais particulares de compreensão sobre uma situação ou várias situações. "A narrativa lida com experiências, não com proposições" (CHARON, 2001, p. 1.898, tradução nossa).

Segundo Brunner (1991), a compreensão de narrativas é uma das habilidades mais precoces que aparecem nas crianças e é a forma de organizar a experiência humana mais largamente utilizada. $\mathrm{O}$ autor ressalta que, na década de 80 , a psicologia ficou ciente de que a capacidade narrativa seria não somente uma capacidade de representar, mas também de constituir a realidade, sendo categórico ao concluir que a narrativa organiza a estrutura da experiência humana (BRUNNER, 1991, p. 8-9).

Estudos descrevem o uso da metodologia de Medicina Narrativa como ferramenta para pesquisas no campo da saúde. Favoreto e Cabral (2009) apresentam uma análise acerca da ampliação dos significados, através das narrativas, sobre o processo saúde-doença em portadores de doenças crônicas que participaram de um grupo operativo de educação em saúde. Em outro estudo, Favoreto e Camargo Jr. (2011) discutem as possibilidades da incorporação conceitual e operativa da narrativa como ampliação do saber e da prática clínica no âmbito da atenção primária à saúde. $\mathrm{Na}$ análise considera-se que a resolutividade da atenção primária seria beneficiada por uma ampliação da dimensão dialógica e hermenêutica dos profissionais de saúde (FAVORETO; CAMARGO JR., 2011, p. 473 e 481).

Em sendo assim, verificada a possibilidade da aplicação metodológica da medicina narrativa, as perguntas que nortearem este estudo foram: como se constitui a experiência humana de quem vive violência urbana e se queixa de sintomas psiquiátricos? O que o acesso à experiência através da narrativa pode revelar sobre a relação entre violência urbana e incidência de transtornos mentais? 
Cabe, de imediato, ressaltar que o acordo com os entrevistados foi a não divulgação do nome da comunidade; portanto, este não será revelado ao longo do artigo. Os entrevistados foram selecionados através de interconsultas realizadas em conjunto com a equipe de saúde da família, tendo uma demanda de saúde mental e a temática da violência urbana como elementos principais. A autora principal do artigo foi psiquiatra matriciadora de um NASF - Núcleo de Apoio à Saúde da Família. O matriciamento em saúde mental teve sua estruturação e ampliação na cidade do Rio de Janeiro, a partir de 2009, proporcionando a implantação dos Núcleos de Apoio à Saúde da Família com equipes compostas, dentre outros, por profissionais de saúde mental trabalhando nas Clínicas da Família. Os NASFs atuam no cuidado compartilhado dos pacientes.

\section{Metodologia}

Dentre 606 interconsultas realizadas em 2016 e 544 realizadas até setembro de 2017 (dados do sistema MedicineOne / Prontuário Eletrônico), podemos dizer que a temática violência urbana se colocava com intensidade na grande maioria dos atendimentos, causando grande impacto no trabalho em curso e produzindo a questão para este artigo. Para além das interconsultas, que são consultas conjuntas, e visitas domiciliares, participação em experiências do território, como grupos e discussóes comunitárias, foi atividade realizada pela autora principal do artigo. Das interconsultas realizadas, foram escolhidas as três participantes para serem entrevistadas, e a seleção se deu por dois fatores principais. Primeiro, o impacto causado pelas histórias durante as interconsultas, uma vez que os relatos produziram discussóes em equipe acerca da interrelação violência urbana e impacto na saúde, possibilidades e limites do cuidado oferecido e, segundo, a clareza das participantes quanto ao pedido de cuidado em saúde mental.

As três entrevistadas são pacientes regulares da Clínica da Família e seguem em acompanhamento. Elas assinaram o TCLE com o acordo de não divulgação de seus nomes e do nome da comunidade em questão. Tal certeza de não divulgação, acreditamos, permitiu uma maior liberdade de expressão na entrevista, um testemunho mais livre de medo, mais acessível ao que realmente desejassem expressar. As entrevistas foram semiestruturadas, seguindo três norteadores: "fale sobre a sua experiência na comunidade em que vive"; "como a violência urbana 
afeta ou afetou sua vida"; "em que a busca por tratamento está relacionada às experiências com a violência".

As entrevistadas estão em uso de medicação antidepressiva, e uma delas faz uso também de benzodiazepínico em processo de retirada. Até a data da escrita deste artigo, uma estava em tratamento há mais de dez anos; outra, há um ano e quatro meses; e a terceira, há seis meses em acompanhamento de saúde mental, sendo que há dois meses precisou iniciar antidepressivo. Esta apresenta, ainda, um quadro de psoríase pustulosa generalizada, atualmente sob controle, desencadeado há dois anos, segundo ela após vivenciar uma situação de violência. Duas entrevistadas tiveram pessoas da família - uma a neta; outra, o filho - assassinados em conflitos armados na comunidade.

Conduzir a escuta dos testemunhos exigiu da autora principal deste artigo a tarefa de não se emocionar e, ao mesmo tempo, se manter empática e cuidadosa para que o processo fosse uma construção das entrevistadas de forma compartilhada com a entrevistadora. Os testemunhos duraram de 40 minutos a uma hora, foram gravados e posteriormente transcritos. Após a transcrição, as narrativas foram escritas com fidelidade ao original transcrito. Com o objetivo de não revelar a comunidade, conforme acordado, toda vez que as entrevistadas mencionavam o nome do lugar onde vivem em suas narrativas, este foi trocado pela palavra "território".

O presente estudo foi submetido à Plataforma Brasil e avaliado pelo Comitê de Ética e Pesquisa do Instituto de Psiquiatria da UFRJ, sendo aprovado sob CAAE 74926017.0.0000.5263.

\section{Narrativas}

\section{"Até hoje fiquei com essa marca"}

\footnotetext{
A minha história começa com uma guerra que não tem nada a ver com os moradores, que náo tinha nada a ver comigo, que só pega em gente inocente. Era um dia como outro qualquer, eu nunca imaginei que iria ser o dia mais triste da minha vida. Ele estava na lanchonete, todo mundo correu, eles chegaram atirando... pegou um tiro na cabeça dele. Ele ficou lá, no chão, era tarde, ninguém para socorrer, minha sobrinha que ajudou e ele chegou vivo no hospital... Eu só sei disso, um tiro pegou na cabeça dele, ele teve derrame cerebral, meu chão desabou, eu me dopei e não quis saber de mais nada. Não consegui nem ir ao enterro e até hoje fiquei com essa marca.

De uma hora para outra, a vida muda toda... o território era um lugar que eu gostava de viver, do lado que eu moro eu não via tanto problema, quando entrava a polícia eu nem
} 
via e eu não tinha ninguém envolvido também... De repente, o chão acabou, desabou... me ofendeu demais, eu me danei e a relação com o território mudou muito, evito até sair na rua, tomei pavor do território.

O que que é essa guerra? Um quer pegar o morro do outro, é isso? É briga de poder, é isso? Eu não entendo nada, via uns meninos que estavam no morro e outros meninos que chegaram para pegar o morro deles. Iam e viam brigando por poder e ficavam em guerra. Agora ficaram os que tomaram o morro. E quem sofreu? Meu filho e outro menino lá inocente... Sabe, eu sinto um desejo de vingança... É eu sinto sim... Acho que deveriam acabar com eles que fizeram o que fizeram com meu filho... Será que eles estão lá com as mães deles? E eu aqui que me danei, sem meu filho! Ele era trabalhador, tinha a loja dele... Até hoje não consigo mexer nas coisas dele, na moto dele, na loja dele... está tudo lá... Eu sinto ódio, raiva... É táo estranho, nunca tinha sentido isso antes, nunca havia acontecido nada parecido comigo. Já faz dois anos, mas eu ainda sinto assim...

Dá um medo de enlouquecer... Eu procurei tratamento porque fiquei quase dois meses trancada no quarto, com raiva, culpando todo mundo e sem aceitar... Hoje os remédios ajudam muito... Como tem pensamento, é muito pensamento, pensamento ruim demais que o remédio ajuda a passar... à noite entấ... Tomo banho, tomo remédio e consigo dormir... A perda é a pior coisa que tem. Sei lá, se ele morresse de acidente de moto ou doente, quem sabe eu aceitasse, mas de tiro... Se ele se misturasse, eu até aceitava, porque aí eu estou esperando... Só que ele era trabalhador. De outra forma, talvez eu nem sofresse tanto assim. Eu até passei a achar que Deus não existe. É muito pensamento, preciso dos remédios... Tem hora que eu penso, será que ele morreu mesmo? Minha mente fica muito nesses pensamentos, pareço que vou endoidar.

Eu era uma pessoa alegre, me distraía muito... Nunca tinha pensado em vingança... Eu costuro, trabalho fazendo roupas e a costura é a minha salvação. (Celeste - nome fictício).

Celeste aceitou fazer a entrevista após acordarmos o sigilo de seu nome e disse achar fundamental que sua história fosse divulgada. Entrou na sala, assinou o TCLE e ficou à vontade, pois já era conhecida da entrevistadora. Emocionou-se em vários momentos e quis continuar. Ao fim, saiu dizendo que o testemunho tinha sido muito importante para ela. De sua narrativa podemos levantar elementos importantes para uma análise mais aprofundada que faremos adiante: a percepçáo de um não entendimento efetivo da violência reinante no "território", a nomeação dessa violência como guerra e um distanciamento seu dessa guerra, uma forte sensação de injustiça e desejo de vingança, acompanhadas da angústia ante a novidade dessas sensaçôes subjetivas e a influência desses elementos para dificultar a elaboração do luto. Em sequência, vemos a violência como produtora de "desterritorializaçáo" afetiva e como todos esses elementos levam a seu sofrimento psíquico. 


\section{"Eu sou a dona da minha casa, mas não a proprietária"}

Vinha um táxi, dia normal, eu estava em casa, com 14 anos, quando, de repente, o motorista foi tirado bruscamente do carro, levado para a parte de trás da minha casa e o próximo momento foi ouvir tiros e ver um lençol descendo ensanguentado. Um traficante da época o havia reconhecido como policial e eu havia tido a minha primeira experiência com a violência na comunidade.

Comecei ali a vivenciar uma violência sobre a qual não se pode falar, não pode chamar ajuda e só resta chorar. E o que eu fiz foi chorar e chorei muitas vezes porque foram muitos outros fatos. Ah, a minha amiga... a máe não pôde nem enterrar a filha! $\mathrm{O}$ traficante quis namorar, ela não quis, souberam que ela estava saindo com um policial e mataram minha amiga. E a droga que eu não conhecia, só sabia que existia, de repente estava na porta da minha casa. Tudo isso sem nada poder falar. São muitas relaçôes violentas e eu não consigo entender como a gente tem que ficar nesse lugar e ter esse relacionamento com aquele que me agrediu e que agrediu quem você ama. Eu convivo com isso, mas é uma angústia enorme, me agride de uma forma... Eu absorvo, não aceito... Não poder expor o que está sentindo! Já pensou o que é isso?

O silêncio sobre a violência é muito forte para mim, é você se sentir impotente, mas ao mesmo tempo consciente de que não pode falar, não pode fazer nada... Presenciou uma cena de violência... Alguém batendo em alguém... Não posso falar "Hey, não bate não. Lembra, ele brincou com você, vocês cresceram juntos! Esse que você está agredindo, essa que você vai matar jogou bola ou brincou de boneca com você!” Simplesmente, não posso! E não posso porque vou sofrer as consequências, eu falo, mas o outro não fala...

Uma outra vivência que eu tenho muito intensa também e que eu sempre discuto é a de ser dona, e não proprietária da minha casa. O que é ser dona e não proprietária? Pense em duas situaçóes no território, uma de um traficante na porta da sua casa e outra de uma operaçáo policial no território, com a polícia chegando à sua casa. A primeira, um traficante velho conhecido forçando a porta da sua casa, insistindo em entrar e, quando você diz que não pode, é agredida com todos os palavrōes e ameaçada que não deveria se meter naquela situação. Só que você está na sua casa, mas ele é o proprietário que se acha no direito sobre a sua casa. Na segunda situaçáo, policiais entram derrubando toda a roupa do guarda-roupa, arrancam a porta, você é tratada como uma traficante, com uma agressividade gigantesca. E aí vem a ordem: "Fica lá fora! Você tem que ficar lá fora. Entendeu?!” De novo, você é a dona e não a proprietária! Eu me senti de uma maneira que nem sei me expressar quando isso aconteceu. Foi como se estivessem rasgando a minha alma. Eu ficava sem dormir, mas achava que iria passar.

Vejo a polícia com o dever de proteger, existe o certo e o errado, mas ela também deve me proteger, mas me agride! Aí também sofri agressão de traficante que forçou a entrada na minha casa e me agrediu verbalmente. Foram muitas as experiências de violência com os dois lados. Essas experiências produziram em mim sensaçóes que eu não tinha antes, sobre quem eu sou. Ser negra, moradora de comunidade nunca tinha sido uma questão para mim. Sempre gostei da minha cor, da minha história, de quem eu sou filha. Entretanto, tudo isso me fez ver que é um problema você ser negro, é um problema você ser pobre, é um problema você morar numa comunidade. 
As pessoas me perguntam o porquê de eu não ir embora, mas sair de uma comunidade para ir para outra não vejo como saída. Aqui no território eu sou conhecida, mas ainda assim, para mim, nada disso é normal. Tudo isso eu não trato como humilhação, mas vejo como ser invadida. Não poder dizer o que sinto, eu não poder ser quem eu sou. Ter que me mascarar. Receber a polícia e ser impedida de dizer "Você tem um mandado?". Se eu falar, tanto faz com a polícia ou traficante, vou sofrer violência física... Eu sei que tenho que morrer, mas eu não quero morrer. A vida pode estar uma porcaria para o mundo e para mim, só que é a minha vida e eu quero a minha vida, enquanto eu ainda tenho tempo, eu quero esse tempo!

São tantas coisas para pensar, tanta coisa... que eu precisei de tratamento. Isso vem me corroendo, me rasgando, como se alguém estivesse enfiando uma faca dentro de mim. Alguns anos se passaram, eu fui dando conta, mas foi crescendo, crescendo. Eu sofria, não dormia, depois não pensava mais, mas cresceu tanto que ficou gigante, explodiu na psoríase e aí eu pensei que náo dava mais, eu precisava procurar ajuda. Os fantasmas ficavam rondando minha mente e mente vazia, oficina do diabo... Comecei o antidepressivo há um mês e por enquanto está me ajudando... Eu não sou uma pessoa menor! Eu mereço respeito, sim! Eu tenho direito, sim! Só que não me é dado. (Lucíola - nome fictício).

Lucíola aceitou o pedido da entrevista também com a certeza do sigilo de seu nome. Nas interconsultas, trazia muito a questáo de achar "besteira" muitos de seus pensamentos e, ao receber a validação de importância pela equipe que a escutava e, inclusive, através do convite para ser entrevistada, disse que isso a fez querer realmente dar seu testemunho. Chegou antes do horário marcado, assinou o TCLE e aceitou bem a gravação. De sua narrativa levantamos elementos a serem aprofundados adiante: o encontro com a violência e com o silenciar sobre ela, as relaçôes estabelecidas pelo poder social da violência no cotidiano da comunidade demarcando impossibilidade de autonomia sobre seus bens e sobre seu próprio desejo e marcando reconstruçôes identitárias de raça e classe social, seguindo com os efeitos desses elementos em sua saúde mental.

\section{"No dia que eu sair, eu deixo o meu calçado e entro no carro descalça"}

São 46 anos vivendo nesse território, tenho muita história aqui, três filhos criados e uma vida de felicidade que acabou há dez anos em dezembro de 2007. Muito difícil reviver aquele dia que começou com uma incursão policial e nós, sabedores disso, fomos nos proteger no quarto - eu, meu marido e minha neta. Após mais ou menos uma hora, tudo calmo, as pessoas na rua, minha neta pediu para lanchar. Foi a gente acender a luz da copa, começaram a atirar. Acertaram nela e no meu marido, nela no abdômen e nele dois tiros de raspão no braço e na barriga. Eu não levei tiro, pois estava na cozinha. 
Seguiu-se a saga para levar os dois para o hospital, os policiais não ajudaram, os vizinhos é que se mobilizaram para levar. Um dos carros estava com o pneu estourado por tiro... da polícia... e tivemos que procurar outro carro.

No hospital, ela viajou, minha neta viajou... Eu estava em desespero e meus familiares não me deixaram ficar lá no hospital. Táo boa era a minha vida e a minha rua antes disso tudo. Minha rua era táo calma, os vizinhos se sentavam na porta para ficar conversando até tarde, minha casa era uma casa de festa. E hoje? Hoje é tristeza e simplesmente solidão. Uma tristeza que vai consumindo tudo. Nós lutamos muito, constituímos advogado, processamos o Estado, mas isso não trouxe alívio ou um ânimo melhor. A lembrança dela está em tudo, na comida que eu vou comer, na cadeira dela que está na copa e até hoje ninguém senta.

Eu atravessei uma sensação de muita revolta, passei momentos de viver só chorando e decidi que precisava de tratamento. Fui atendida por psicologia e psiquiatria. O que estava também muito difícil de lidar é que eu passei a ter muito medo, muito medo da polícia. Medo que me fez um dia até desmaiar numa blitz. Pararam nosso carro e acharam que tinha droga, meu filho argumentou que nós éramos a família da menina do território, foi quando um dos policiais lembrou e nos deixou ir, mas eu já havia desmaiado. Eles entram em todas as casas aqui no território, e eu dou graças a Deus que eles nunca entraram na minha casa, mas também se entrarem só encontrarão tristeza, mais nada!

Em todos esses anos, eu sempre pensei que se eu não tivesse me apegado muito em Deus, eu teria enlouquecido. Eu já achei que pudesse enlouquecer... Um dia estava com meu marido e uma das minhas netas na rua andando... Vinha uma carreta e pensei em me jogar embaixo dela para parar de sofrer... Quando minha neta falou comigo, o pensamento parou e me veio outro pensamento: que fraqueza é essa, meu Deus?! De fato, é muito sofrimento, é uma dor tão grande. Quem sabe se ela tivesse morrido de dor de garganta, uma infecção ou qualquer outra coisa eu conseguiria ficar mais conformada, mas de bala perdida... Sabendo que quando a gente acendeu a luz e chegou na copa o maldito nos viu, pois ele estava na parte de cima da Assembleia de Deus!! E se meu marido não tivesse sobrevivido, aí eu acho que não estaria aqui, contando essa história.

Eu penso muito. Muitos questionamentos. Botaram UPP, para quê? Continua ainda pior. Temos que ver, ouvir e ficar calados. A marca da bala ainda está lá e todas as vezes que eu olho não é fácil. Tenho muita vontade de me mudar do território, minha neta me pedia para náo vender a casa, mas eu não estou aguentando mais viver aqui. Dez anos depois e está piorando. Passamos 12 dias com a polícia na comunidade e foram 12 dias de terror. Cada tiro, uma lembrança e relembro tudo. E era tiro a noite inteira. Minha neta tinha tanto medo do caveiráo, da polícia, ela sentia pavor deles, parecia que ela estava adivinhando... Nesses 12 dias as portas da minha casa ficaram fechadas e dentro uma tristeza imensa. A gente sente uma tristeza de morar no morro. E eu que amava tanto a minha casa, hoje eu não amo mais, não amo não... Não amo mesmo. E não gosto de onde eu moro, de sentir medo 24 horas por dia.

O que está por trás disso tudo eu acho que é o maldito tráfico, a polícia puxando de um lado e os bandidos de outro. Nós, moradores, ficamos em casa com medo e eles brigando, 
porque para mim entre os dois não tem diferença. Quando chegam na casa das pessoas, chegam chutando arrebentando tudo! Acho que Deus plantou um anjo na minha porta, para eles nunca terem entrado aqui!

Meu filho me diz que falta pouco para a gente sair do território, e eu tenho esperança de que a gente consiga mesmo sair. E eu falo para ele que no dia em que eu for embora, vou chegar lá embaixo do morro, deixar o meu calçado e entrar no carro descalça. Não quero levar nem uma pedra, uma areia, nada no calçado. Ele me pergunta: "É tanta revolta assim, mãe?" E eu digo: "É sim filho, é muita revolta!" (Analice - nome fictício).

Analice é bastante conhecida no território, muito falante na sala de espera da clínica, o que contrastou com o momento em que a encontramos para a interconsulta e soubemos de sua história. A tristeza inundou o atendimento e foi muito impactante para a equipe envolvida. Ela aceitou a entrevista rapidamente, disse que já havia participado de muitas entrevistas e que para ela não seria um problema. Entretanto, após a gravação, disse que havia sido diferente de tudo o que já havia feito e que o testemunho foi muito importante para ela. De sua narrativa depreendemos elementos que já começam a dialogar com as narrativas de Celeste e Lucíola, como a violência como forma de produção de "desterritorializaçáo" afetiva, a revolta como processo de dificuldade na elaboração do luto e o silêncio como modo operante de relação social para lidar com a violência. Analice aponta também a repetição de eventos violentos e as repercussôes subjetivas disso gerando sofrimento psíquico para ela.

\section{Liçóes aprendidas com o acesso à experiência pelas narrativas}

Como pontua Charon (2001), descrevendo o modelo de medicina narrativa no seu engajamento empático médico-paciente,

[...] à medida que o médico escuta o paciente, ele ou ela segue a narrativa, o fio da história,
imagina a situaçáo do narrador (o biológico, familiar, situaçáo cultural e existencial),
reconhece os múltiplos e muitas vezes contraditórios significados das palavras usadas e
eventos descritos e, de alguma forma, entra e é movido pelo mundo narrativo do paciente
(CHARON, 2001, p. 1.898-1.899, traduçáo nossa).

Dessa forma, acontece uma ligação com a experiência vivida pelo narrador que produz conhecimento. Assim, da conexão empática com as narradoras Celeste, Lucíola e Analice conseguimos nos mover por seus relatos, acessar experiências pelas narrativas e depreendemos os elementos elencados acima, os quais analisaremos agora, pautando-os como os que sinalizam a relação violência e agravos à saúde mental das entrevistadas. 
Primeiramente, vemos a "desterritorialização" afetiva como elemento. Este fortemente demarcado por Celeste e Analice como ilustrado em passagens — "De repente, o chão acabou, desabou [...] me ofendeu demais, eu me danei e a relação com o território mudou muito, evito até sair na rua, tomei pavor do território." / "E eu que amava tanto a minha casa... Hoje não amo mais" —, fazendo-nos pensar que os eventos violentos impactam as relaçóes de pertencimento territorial, afetando a existência psíquica e social na comunidade onde vivem. São duas narradoras que sofreram com conflitos armados e perdas de entes queridos assassinados, o que levou o território a ter uma relação diferenciada para elas para sempre. Analice demarca, ainda, com maior clareza o desejo de saída e a angústia ante essa impossibilidade. A ruptura afetiva com o território se dá, mas a ruptura efetiva náo pode acontecer por limites objetivos. Essa é uma marca relevante em sua narrativa que assinala a condição de sofrimento. Já Lucíola aponta a saída do território como possibilidade, mas como uma ação sem potência de mudança, e registra ainda alguma marca de pertencimento, como podemos ver no fragmento: "As pessoas me perguntam o porquê de eu náo ir embora, mas sair de uma comunidade para ir para outra não vejo como saída. Aqui no território eu sou conhecida, mas ainda assim, para mim, nada disso é normal". Entretanto, Lucíola discorre sobre a vida no território como potente geradora de sofrimento para ela, demarcando as dificuldades nas suas relações pessoais e vínculos afetivos, mesmo não acreditando em caminhos de saída: "São muitas relaçôes violentas e eu não consigo entender como a gente tem que ficar nesse lugar e ter esse relacionamento com aquele que me agrediu e que agrediu quem você ama”. A "desterritorialização" afetiva para ela se dá com nuances diferentes de Analice e Celeste, talvez pela sua experiência de outra ordem com a violência urbana.

Lembrando o conceito de território, ${ }^{1}$ sua importância para a saúde pública, o elemento de "desterritorializaçáo" levantado pela experiência das narradoras nos remete a indagaçóes feitas em estudos sobre a geografia da saúde no Brasil, usandose os conceitos de Milton Santos:

Outro ponto importante que deve ser considerado nas análises territoriais urbanas é o sentido da palavra territorialidade como sinônimo de pertencer àquilo que nos pertence [...] Aliás, pode-se fazer uma ótima aproximação entre o sentido dos termos territorialidade e cidadania. Por cidadania compreendem-se os direitos sociais, o direito ao entorno, à moradia, à saúde, à educação [...] em suma, o direito ao território urbano. Ora, essa reflexão faz emergir uma indagação importante: não seria a construção de espaços de não cidadãos [...] a explicação para os eventos de doença na cidade? Em outras 
palavras, não seria a produção de territórios de "não cidadãos" a razão para determinados comportamentos biológicos da sociedade? (FARIA; BORTOLOZZI, 2009, p. 38-39)

Em sendo assim, seria a experiência aqui descrita um sinalizador de como a violência urbana produz impactos na relação entre territorialidade, pertencimento e cidadania, determinando agravos à saúde por produção de territórios de não cidadãos?

Outro elemento levantado é a questão da elaboração do luto. Vemos em Celeste e Analice um luto prolongado. Falam de seus entes queridos com muita emoção, com lembranças antigas contadas como se fossem recentes, a marca de um luto prolongado como gerador de forte sofrimento psíquico. Em ambas as narrativas, se revela a experiência do sentimento de vingança e revolta, na sensação de que se a morte tivesse se dado de outra forma, que não por conflito armado, alguma aceitação pudesse acontecer. Os fragmentos abaixo ilustram o elemento elencado aqui:

A perda é a pior coisa que tem. Sei lá, se ele morresse de acidente de moto ou doente, quem sabe eu aceitasse, mas de tiro... Se ele se misturasse, eu até aceitava, porque aí eu estou esperando... Só que ele era trabalhador. De outra forma, talvez eu nem sofresse tanto assim. [...] Tem hora que eu penso, será que ele morreu mesmo? (Celeste).

Quem sabe se ela tivesse morrido de dor de garganta, uma infecção ou qualquer outra coisa eu conseguiria ficar mais conformada, mas de bala perdida... Sabendo que quando a gente acendeu a luz e chegou na copa o maldito nos viu, pois ele estava na parte de cima da Assembleia de Deus! (Analice)

Em estudo que investiga o luto de mães que perderam filhos por homicídio, encontramos similaridades com o que Celeste e Analice apontam. Os autores discutem, na investigação de cinco mães enlutadas, que existem sentimentos vivenciados de justiça e punição dos culpados, o desejo de compreender o que aconteceu e a necessidade de se expressar sobre a tragédia vivenciada, o que pode caracterizar possível fator de risco para o desenvolvimento de um luto complicado. Além de apontarem que, diante de uma morte não natural, que náo seja por doença, envelhecimento, a perda torna-se inaceitável, especialmente quando ocorre por ato de crueldade dos homens, tornando-se inadmissível para as mães (ALARCÃO; BARROS; PELLOSO, 2008, p. 5).

Lucíola traz mais um elemento significativo que trata do silenciar sobre a violência como algo que a devasta subjetivamente. Códigos impostos que normatizam o cotidiano dos moradores das comunidades violentas são expostos 
pela experiência de Lucíola. Ver, ouvir e calar, uma norma que determina que você seja conivente com açóes que violam a vida, o que você, muitas vezes, náo deseja ser. Esse determinar dos códigos da violência sobre seus desejos demonstra ser o grande gerador de sua angústia, assim como o determinar desses códigos sobre a sua capacidade de ser dona e/ou proprietária de seus bens. Enfim, a violência impondo submissão subjetiva e perda de autonomia. O silêncio na narrativa de Lucíola conversa com Analice, que aponta que calar se faz necessário para ela também, como demonstramos em suas palavras:

O silêncio sobre a violência é muito forte para mim, é você se sentir impotente, mas, ao mesmo tempo, consciente de que náo pode falar, não pode fazer nada... Presenciou uma cena de violência... Alguém batendo em alguém... Não posso falar [...] Simplesmente, não posso! E não posso porque vou sofrer as consequências, eu falo, mas o outro não fala. (Lucíola).

Botaram UPP, para quê? Continua ainda pior. Temos que ver, ouvir e ficar calados. (Analice).

Em seguimento, apresentamos outro elemento muito pungente da narrativa de Lucíola que se refere à questão identitária, visto que ela cita o encontro com a violência urbana do território como "ressignificador" de sua condição de negra e favelada, o que antes não era um problema passa a ser após esse encontro:

Foram muitas as experiências de violência com os dois lados. Essas experiências produziram em mim sensaçóes que eu não tinha antes, sobre quem eu sou. Ser negra, moradora de comunidade, nunca tinha sido uma questão para mim. Sempre gostei da minha cor, da minha história, de quem eu sou filha. Entretanto, tudo isso me fez ver que é um problema você ser negro, é um problema você ser pobre, é um problema você morar numa comunidade. (Lucíola).

Os elementos elencados anteriormente pela experiência de Lucíola nos remetem aos estudos que utilizam a teoria de Foucault. As três técnicas de poder estudadas por Foucault são a disciplinarização como tecnologia de controle, sobretudo dos corpos adestrados, a normalização como controle positivo do comportamento e do pensamento e o biopoder como controle da população, tanto em seu fluxo quanto em tamanho. Especificamente sobre o biopoder, Foucault levanta que um dos aspectos da forma de gestão política da população resulta de uma nova modalidade de racismo, de caráter estatal, sustentada por princípios científicos, havendo uma inscrição do racismo nos mecanismos do Estado (CASTELO BRANCO, 2009, p. 32). Lucíola refere-se justamente circulando entre poderes que a controlam em seu 
comportamento, que buscam adestrar seus atos e que determinam sua raça como problema, fazendo-a sentir-se submetida a uma condição de inferioridade. Podemos inferir que a experiência aqui revelada indica que as relaçôes de poder determinadas pela violência urbana e de Estado produzem uma forte condição de sofrimento.

Não há como não discutir, então, o indicativo violência de Estado presente nas narrativas. Este é um tema que tem sido pouco discutido na interface com a saúde mental:

Os trabalhos sobre a violência de Estado, especialmente sobre a tortura, violência policial, violência política, frequentam pouco o campo de produçâo no âmbito da saúde mental, embora sejam numerosos no âmbito dos Direitos Humanos, Política e História. Trabalhos sobre as consequências psicossociais da violência de Estado, ainda que numerosos na forma de publicação em livros, são raros na produção regular de periódicos científicos do campo da saúde mental/psiquiatria (DELGADO, 2012, p. 189).

As três entrevistadas apontam uma comunidade submetida à violência policial e à violência do tráfico de drogas, muitas vezes equivalendo as duas violências, o que assinala a problemática dessa equivalência para a política de segurança pública. A violência de Estado e a violência da guerra às drogas são reveladas na experiência como geradora de sofrimento e como determinadora de eventos traumáticos. Como vemos nos seguintes fragmentos:

O que que é essa guerra? Um quer pegar o morro do outro, é isso? É briga de poder, é isso? Eu não entendo nada, via uns meninos que estavam no morro e outros meninos que chegaram para pegar o morro deles. Iam e viam brigando por poder e ficavam em guerra. Agora ficaram os que tomaram o morro. E quem sofreu? Meu filho e outro menino lá inocente... Sabe, eu sinto um desejo de vingança. (Celeste).

$\mathrm{Na}$ segunda situação, policiais entram derrubando toda a roupa do guarda-roupa, arrancam a porta, você é tratada como uma traficante, com uma agressividade gigantesca. E aí vem a ordem: "Fica lá fora! Você tem que ficar lá fora. Entendeu?!" De novo você é a dona e não a proprietária! Eu me senti de uma maneira que nem sei me expressar quando isso aconteceu. Foi como se estivessem rasgando a minha alma. Eu ficava sem dormir, mas achava que iria passar. (Lucíola).

O que estava também muito difícil de lidar é que eu passei a ter muito medo, muito medo da polícia. Medo que me fez um dia até desmaiar numa blitz. Pararam nosso carro e acharam que tinha droga, meu filho argumentou que nós éramos a família da menina do território, foi quando um dos policiais lembrou e nos deixou ir, mas eu já havia desmaiado. (Analice).

Para pensarmos no que o acesso às experiências através das narrativas pode nos dar de dicas - inicialmente - a fim de avaliar a relação entre violência urbana e incidência 
de transtornos mentais, foi necessário recorrer a Seligmann-Silva (2000), em seu texto "A História como trauma" na discussão sobre o Holocausto e suas possibilidades de apreensão e representação. No texto, o autor apresenta a concepção de Shoah como um objeto que escapa à representação justamente devido ao seu "excesso", algo sem limites e irrepresentável, e inscreve o Shoah na experiência do Holocausto (SELIGMANNSILVA, 2000, p. 84-85). Podemos pensar que quem vive violência urbana nos excessos da violência de Estado estabelece algum paralelismo com o que Seligmann-Silva vai descrever como Shoah. No decorrer de sua argumentação, o autor aproxima-se de Freud e do seu conceito de trauma. "O trauma, para Freud, é caracterizado pela incapacidade de recepção de um evento transbordante [...] trata-se [...] da incapacidade de recepção de um evento que vai além dos "limites" da nossa percepção e torna-se, para nós, algo sem forma” (SELIGMANN-SILVA, 2000, p. 84).

\section{Considerações finais}

As entrevistadas apontam uma dimensão de excesso, de perplexidade, de invasão, experiências que vão além dos seus limites, o que nos permite supor suas experiências na ordem do trauma.

Não nos cabe e nem interessa aqui discutir os diagnósticos recebidos pelas pacientes, mas o que a dimensão de suas experiências nos parece apontar, e esse apontamento nos parece dirigir para a experiência traumática. E, ainda, nos demonstra ser a experiência traumática a geradora da demanda por cuidado em saúde mental, associada aos demais elementos geradores de agravos descritos anteriormente, tornando muito mais complexa a questáo e dificultando reduzir a temática à incidência de transtornos mentais.

Acima de tudo, o que a experiência de Celeste, Lucíola e Analice nos ensina é a condição de sofrimento a que estão submetidos os moradores das comunidades em situação de violência da cidade do Rio de Janeiro. Suas vozes são vozes de resistência que, através deste artigo, se fazem ecoar. Suas experiências sinalizam o trauma, a "desterritorialização", o prolongamento do luto, a intervenção do poder dos códigos da violência na autonomia subjetiva e identitária como questôes que fazem interface entre violência urbana e agravos à saúde mental. Suas narrativas sinalizam a dor subjetiva que não cala e precisa ser ouvida.

O que apresentamos aqui é uma discussão inicial, fruto desse estudo preliminar que pretende aprofundar a temática em análises posteriores, ampliando a investigação 
ao acessar mais experiências e identificar se os elementos elencados neste artigo podem, de alguma forma, ser verificados em estudos sobre violência urbana e saúde mental, utilizando o modelo medicina narrativa em maior escala. ${ }^{2}$

\section{Referências}

ALARCÃO, A. C. J.; BARROS, M. D. C.; PELLOSO, S. M. A morte de um filho jovem em circunstância violenta: compreendendo a vivência da mãe. São Paulo. Revista Latino-Americana de Enfermagem, v. 16, n. 3, 2008.

BRUNNER, J. A construção narrativa. Critical Inquiry, v. 18, n. 1, p. 1-21, 1991.

CARDOSO, F. L .M. G. et al. Homicídios no Rio de Janeiro, Brasil: uma análise da violência letal. Ciência \& Saúde Coletiva. Rio de Janeiro, v. 21, n. 4, p. 1.277-1.288, 2016.

CASTELO BRANCO, G. Racismo, individualismo, biopoder. Revista de Filosofia. Curitiba, v. 21, n. 28, p. 29-38, jan.-jun. 2009.

CHARON, R. Narrative medicine: a model for empathy, reflection, profession, and trust. JAMA, v. 286, n. 15, p. 1.897-1.902, 2001

DELGADO, P. G. G. Violência e saúde mental: os termos do debate. O social em questäo. Rio de Janeiro, ano XV, n. 28, p. 187-198, 2012.

FARIA, R. M.; BORTOLOZZI, I. A. Espaço, território e saúde: contribuiçôes de Milton Santos para o Tema da Geografia da Saúde no Brasil. Curitiba: Editora UFPR, 2009.

FAVORETO, C. A. O.; CABRAL, C. C. Narratives on the health-disease process: experiences in health education operational groups. Interface - Comunicação, Saúde, Educação, v. 13, n. 28, p. 7-18, jan.-mar. 2009.

FAVORETO, C. A. O.; CAMARGO JR, K. R. Narrative as a tool for the development of clinical practice. Interface - Comunicaşão, Saúde, Educação, v. 15, n. 37, p. 473-83, abr.-jun. 2011.

GONÇALVES, H. C. B.; QUEIROZ, M. R; DELGADO, P. G. G. Violência urbana e saúde mental: desafios de uma nova agenda? Fractal: Revista de Psicologia. Rio de janeiro, v. 29, n. 1, p. 17-23, jan.-abr. 2017.

PERES, M.F.T.; RUOTTI, C. Violência urbana e saúde. Revista USP. São Paulo, n. 107, p. 6578, out.-dez. 2015.

SAQUET, M. A.; SILVA, S. S. Milton Santos: concepçôes de geografia, espaço e território. GeoUERJ. Rio de Janeiro, ano 10, v. 2, n. 18, 2008.

SELIGMANN-SILVA, M. A História como trauma. In: Catástrofe e Representação. São Paulo: Escuta, 2000. 


\section{Notas}

1 "Milton Santos elege as categorias forma, função, estrutura, processo e totalidade como as principais que devem ser consideradas na análise geográfica do espaço; este constitui a categoria principal e auxilia na compreensão do território. O espaço, dessa maneira, é construído processualmente e contém uma estrutura organizada por formas e funçôes que podem mudar historicamente em consonância com cada sociedade" (SAQUET; SILVA, 2008, p. 32).

${ }^{2}$ P. C. Schmid realizou a coleta e análise dos dados e redigiu o artigo. O. D. Serpa Junior realizou a análise dos dados e a discussão teórica. 


\section{Abstract}

\section{Urban violence and mental health: first person narratives}

The article presents a qualitative study about the theme of urban violence and mental health through the narratives of patients of a family clinic located in a very violent area. The Narrative Medicine methodology was used, and three patients from the family clinic were interviewed, selected for their request for mental health care and intense experience with violence. The narratives are analyzed, recorded, and pointed the elements that may indicate the harms provided by the violent experience to the mental health of the interviewees, namely trauma, affective "deterritorialization", prolongation of mourning, and intervention of the power of violence codes in subjective and identity autonomy.

> Keywords: urban violence; mental health; narratives. 